\title{
ROMI IN ROMSKA NASELJA V SLOVENIJI
}

Jernej Zupančič: Romi in romska naselja v Sloveniji. Zbirka Razprave FF. Znanstvena založba Filozofske fakultete Univerze v Ljubljani, 255 str. Ljubljana, 2015

Romska naselja in njihovi prebivalci so bili v zadnjih dveh desetletjih pogosto $v$ središču pozornosti širše javnosti, redkeje pa so se znašli v središču strokovnih raziskav. Knjiga Jerneja Zupančiča tako predstavlja prvo znanstveno delo, ki celostno obravnava problematiko

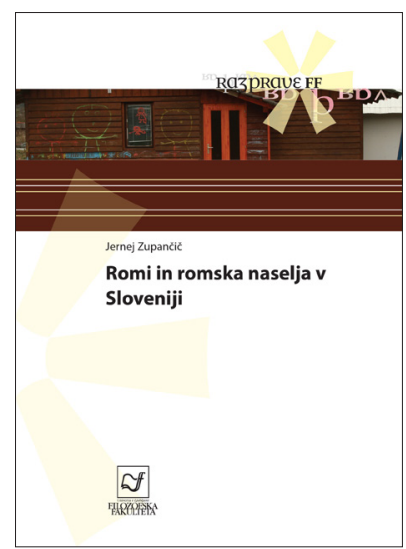
romskih naselij v Sloveniji.

Delo je razdeljeno na šest poglavij in številna podpoglavja. Besedilo dopolnjuje raznoliko kartografsko, statistično in slikovno gradivo (v knjigi je 14 preglednic, 25 zemljevidov in shem, 11 grafikonov in 13 fotografij).

Uvodno poglavje je namenjeno kratki predstavitvi ključnih teoretskih in metodoloških izhodišč, ki so vodila avtorja pri preučevanju romskih naselij. Avtor opozarja, da so romska naselja poseben prostorski, socialni in kulturni pojav $\mathrm{v}$ slovenskem prostoru, $\mathrm{s}$ specifičnim nastankom, strukturo in razvojem. Obenem izpostavlja njihovo dinamičnost, zaradi katere romska naselja intenzivno spreminjajo svojo zunanjo podobo, strukturo in funkcijo. Uvodno poglavje se zaključi s kratkim pregledom oblikovanja romskih skupnosti po svetu.

Drugo poglavje je namenjeno predstavitvi Romov v Sloveniji, v prvi vrsti zgodovini naselitve in podatkom o njihovi številčnosti. Posebno podpoglavje je posvečeno vprašanju njihove teritorialnosti in avtohtonosti. V njem avtor argumentira tezo, da so Romi v določenih delih Slovenije zgodovinsko prisotni in zato predstavljajo avtohtono skupnost.

Romska naselja so v središču tretjega poglavja. Osnovni predstavitvi vseh romskih naselij v Sloveniji sledi opredelitev in opis glavnih značilnosti (lokacije, oblike in strukture) ter razvojnih dejavnikov. Hkrati so predstavljene glavne razvojne faze v njihovem oblikovanju. Poglavje se zaključi s kratko predstavitvijo ključnih problemov, s katerimi se soočajo romska naselja in njihovi prebivalci ter lokalne skupnosti, v katerih se nahajajo.

V četrtem poglavju avtor obravnava infrastrukturno opremljenost naselij. Predstavljeni so podatki o oskrbi s pitno vodo in elektriko, priključenosti na kanalizacijsko omrežje, urejenosti odvoza smeti ter prometni dostopnosti naselij. Zelo natančen popis infrastrukturne opremljenosti je nastal $\mathrm{v}$ okviru dveh raziskav, ki jih je pod avtorjevim vodstvom v letih 2007 in 2010 opravila Strokovna skupina za reševanje prostorske problematike romskih naselij v Sloveniji.

Predzadnje poglavje je namenjeno predstavitvi dobrih praks s področja urejanja romskih naselij. Pri primerih dobrih praks avtor izpostavlja nujnost oblikovanja partnerskega 
odnosa med Romi, lokalno skupnostjo in državo. Izpostavljeni so primeri naselij Pušča v občini Murska Sobota, Vejar (Hudeje) v občini Trebnje, Željne v občini Kočevje in Vanča vas-Borejci v občini Tišina.

Zadnje poglavje - Romska naselja v procesih modernizacije - je bolj aplikativne narave. $\mathrm{V}$ njem avtor ponuja model načrtovalskih posegov, ki naj bi akterjem, vključenim $\mathrm{v}$ reševanje problematike, pomagal pri pripravi strategije vključevanja romskih naselij v slovenski naselbinski sistem. "Koncept določa okvirni potek ukrepov in aktivnosti ter opredeljuje posamezne nosilce in predvideva etapne cilje.« Po mnenju avtorja mora biti strateški cilj urejanja romskih naselij njihova demarginalizacija, dekonfliktualizacija in socialno-prostorska integracija. Hkrati zagovarja tezo, da je možno z načrtnim delom romska naselja v celoti vključiti v slovenski naselbinski sistem, ne da bi pri tem tvegali izgubo romske identitete.

Že uvodoma je bilo omenjeno, da je knjiga Romi in romska naselja $v$ Sloveniji pionirsko delo. Kot takšno prinaša številne nove ugotovitve in spoznanja o romskih naseljih v Sloveniji. Ta predstavljajo za raziskovalce velik strokovni izziv, saj gre za zelo kompleksen pojav, katerega preučevanje zahteva znatno mero iznajdljivosti. Avtor se je tega dobro zavedal, zato je svoje raziskave osnoval na obširnem terenskem delu ter na vzpostavitvi neposrednih stikov s prebivalci romskih naselij in različnimi akterji, vključenimi v reševanje njihove problematike. Prav to daje predstavljenim ugotovitvam in spoznanjem še posebno težo in veljavo.

Knjiga na eni strani ponuja odlične temelje za nadaljnje raziskave, hkrati pa odpira številna vprašanja, probleme in izzive, ki so povezani s procesom preoblikovanja romskih naselij. Pri tem velja izpostaviti avtorjevo opazko, da predstavljene ugotovitve ne želijo biti nabor končnih spoznanj, ampak vodilo k nadaljnjemu poglobljenemu terenskemu preučevanju.

Kot vsako pionirsko delo ima tudi to določene pomanjkljivosti. Med njimi velja izpostaviti določeno mero nesistematičnosti, ki se kaže v mestoma ne najbolj logični delitvi na poglavja in podpoglavja, oziroma $v$ pretirani razdrobljenosti na podpoglavja. Posledično so nekatere teme obravnavane na več mestih, določene ugotovitve pa se tu in tam nekoliko ponavljajo. Med pomanjkljivostmi velja omeniti še relativno površno obravnavo nekaterih teoretsko-metodoloških vprašanj, v prvi vrsti samega pojma romska naselja.

Delo Romi in romska naselja $v$ Sloveniji ni namenjeno le geografom, ampak veliko širši publiki. Vsekakor pa bi moralo postati obvezno branje vseh akterjev, ki se vsakodnevno ali le občasno srečujejo s problematiko romskih naselij. 